\title{
Research on Causes of Job Stress for Workers of Non-Public Sector Banks
}

\author{
S. Selvaraju, Asha Sundaram
}

\begin{abstract}
The most important and critical organizational factor that affects the performance of workers of banking business is Job stress. The role conflict, role ambiguity, role overload, job difficulty, role stagnation and lack of group cohesiveness are significantly and moderately correlated with the level of job stress of workers in non-public sector banks. Hence, the non-public sector banks should provide needed information to their workers to carry out their responsibilities and workers must prioritize their role. The non-public sector banks should clearly define the role of each and every employee and must make interactions among roles of all the workers and the work load of workers should be reduced through additional recruitment of workers or sharing workload among bank workers.
\end{abstract}

Key Words: Workers, Job stress, non-public sector banks

\section{INTRODUCTION}

The banking system in India has come a long way during the last two centuries. Its growth is faster and the coverage is wider since 1969. Conventional banking has steadily changed to modernization in management of credit. In other words, the banking sector in India is witnessing an era of spectacular change with credit policy and operations. Due to financial sector reforms, revolution in information and communication technologies, higher demands from customers and mounting competition have put an enormous pressure in banking sector and also workers to perform better. These transformations affect the psychological, social and economical domains of the bank workers and their relationships. Because of these changes, the bank workers are experiencing strain and stress.

Stress has psychological, physical and emotional impacts and can generate negative or positive feelings. As a positive impact, stress can make workers towards achievements. It can end with a fresh responsiveness and an exhilarating newer perception and that is names as eustress. As a negative effect, it can end with sense of doubt, denial, annoyance and sadness, which in turn can create health problems to workers and is named as distress.

Job stress associates with the occurrence of stress in the work place, employment or occupation. Job stress is a condition of anxiety that is generated when an employee reacts to the work pressures demands that arise out of family, occupation and from external elements and those that are internally created from self-imposed commitments, demands and self-criticism.

Employers in any sector including banking sector must work in the environment which is free from strain and stress. Job stress decreases the job performance of workers and also

Revised Manuscript Received on 14, October 2019.

Dr.S. Selvaraju, Associate professor

(E-mail: selvaraju@ saveetha.ac.in)

(E-mail: chennaiselvaraju@ gmail.com)

Dr.Asha Sundaram, Professor leads to job dissatisfaction and it also makes high pressure on management to make workers fit in both physically and mentally. Job stress also affects concentration, memory, attitude for learning and personality. Thus, it is important to study the causes of job stress for workers of non-public sector banks in Chennai city.

\section{METHODOLOGY}

The Chennai city is chosen for the present study. The bank workers are selected by using random sampling method and the data are collected from 350 workers of nonpublic sector banks through pre-tested and structured questionnaire. The percentage analysis is done to understand socio-economic profile of workers and level of job stress of workers of non-public sector banks. The mean and standard deviation are worked out for causes of job stress for workers of non-public sector banks. The correlation analysis is carried out to study the relationship between causes of job stress and level of stress of workers in non-public sector banks.

\section{RESULTS AND DISCUSSION}

\subsection{Socio-Economic Profile Of Workers Of Non-Public Sector Banks}

It is obvious from the result that $52.00 \%$ of workers of non-public sector banks are males, while, the remaining $48.00 \%$ of workers of non-public sector banks are females. It is clear that $34.86 \%$ of workers of non-public sector banks belong to the age group of 31 - 40 years followed by 21 - 30 years $(27.43 \%), 41$ - 50 years $(23.14 \%)$ and more than 50 years $(14.57 \%)$

The results reveal that $38.86 \%$ of workers of non-public sector banks have educational qualification of postgraduation followed by under graduation (28.29\%), diploma $(19.14 \%)$ and school education $(13.71 \%)$. It is evident that $51.43 \%$ of workers of non-public sector banks are clerks followed by officers $(31.43 \%)$ and managers $(17.14 \%)$.

From the result it is apparent that $39.71 \%$ of workers of non-public sector banks have work experience of $6-10$ years followed by $11-15$ years $(29.72 \%), 1-5$ years $(24.00 \%)$ and more than 15 years $(6.57 \%)$. It is obvious that $32.29 \%$ of workers of non-public sector banks belong to the monthly income group of Rs. 30,001- Rs. 40,000 followed by Rs. 20,001- Rs. 30,000(27.14 \%), Rs. 40,001Rs. 50,000(21.72\%), less than Rs. 20,000(11.71\%) and more than Rs. 50,000(7.14\%). 
The results show that $61.71 \%$ of workers of non-public sector banks are married, while, the rest of $38.29 \%$ of workers of non-public sector banks are unmarried. It is observed that $59.71 \%$ of workers of non-public sector banks belong to the nuclear family and the rest of $40.29 \%$ of workers of non-public sector banks belong to the joint family.

The results reveal that $48.28 \%$ of workers of non-public sector banks have 3-5 dependents followed by less than three dependents $(35.43 \%)$ and more than five dependents $(16.29 \%)$. It is apparent that $46.00 \%$ of workers of nonpublic sector banks are working in branches located in urban area followed by semi-urban area (39.71\%) and suburban area $(14.29 \%)$.

\subsection{Causes Of Job Stress For Workers Of Non-Public Sector Banks}

The causes of job stress for workers of non-public sector banks were analyzed and the results are hereunder presented.

\subsubsection{Role Conflict}

The role conflict of workers in non-public sector banks was studied and the results are shown in Tabular format -1

Tabular format1 : Role Conflict

\begin{tabular}{|l|l|l|l|}
\hline $\begin{array}{l}\text { Sl. } \\
\text { No. }\end{array}$ & Role Conflict & Mean & $\begin{array}{l}\text { Standard } \\
\text { Deviation }\end{array}$ \\
\hline 1. & $\begin{array}{l}\text { I do not get information } \\
\text { needed carryout } \\
\text { responsibilities assigned to me }\end{array}$ & 3.85 & 0.97 \\
\hline 2. & $\begin{array}{l}\text { I am not able to satisfy the } \\
\text { conflicting demands of various } \\
\text { peer level people and my } \\
\text { subordinates }\end{array}$ & 3.89 & 0.79 \\
\hline 3. & $\begin{array}{l}\text { I am not clear on the scope and } \\
\text { responsibilities of my role }\end{array}$ & 3.72 & 0.85 \\
\hline 4. & $\begin{array}{l}\text { I am not clear as to what are } \\
\text { the priorities in my role }\end{array}$ & 3.42 & 0.86 \\
\hline 5. & $\begin{array}{l}\text { I receive incompatible requests } \\
\text { from my subordinates }\end{array}$ & 3.70 & 0.87 \\
\hline
\end{tabular}

Source: Primary Data

The workers of non-public sector banks are agreed they do not get information needed to carryout responsibilities assigned to them, they are not able to satisfy the conflicting demands of various peer level people and their subordinates, they are not clear on the scope and responsibilities of their role and they receive incompatible requests from their subordinates, while they are neutral with they are not clear as to what are the priorities in their role.

\subsubsection{Role Ambiguity}

The role ambiguity of workers in non-public sector banks was studied and the results are shown in Tabular format -2
Tabular format 2 : Role Ambiguity

\begin{tabular}{|l|l|l|l|}
\hline $\begin{array}{l}\text { Sl. } \\
\text { No. }\end{array}$ & Role Ambiguity & Mean & $\begin{array}{l}\text { Standard } \\
\text { Deviation }\end{array}$ \\
\hline 1. & $\begin{array}{l}\text { My role has not been } \\
\text { defined clearly and in } \\
\text { detail }\end{array}$ & 3.79 & 1.10 \\
\hline 2. & $\begin{array}{l}\text { Several aspects of my role } \\
\text { are vague }\end{array}$ & 3.26 & 1.35 \\
\hline 3. & $\begin{array}{l}\text { I am not clear as to what I } \\
\text { have to do in my role }\end{array}$ & 3.30 & 1.22 \\
\hline 4. & $\begin{array}{l}\text { I am enslaved by time } \\
\text { schedule in my work }\end{array}$ & 3.75 & 1.07 \\
\hline 5. & $\begin{array}{l}\text { I feel anxious and } \\
\text { apprehensive even though } \\
\text { I do not know what has } \\
\text { caused it }\end{array}$ & 3.77 & 1.08 \\
\hline
\end{tabular}

Source: Primary Data

The workers of non-public sector banks are agreed with their role has not been defined clearly and in detail, they are enslaved by time schedule in their work and they feel anxious and apprehensive even though they do not know what has caused it, while, they are neutral with several aspects of their role are vague and they are not clear as to what they have to do in their role.

\subsubsection{Role Overload}

The role overload of workers in non-public sector banks was studied and the results are shown in Tabular format -3

Tabular format3 : Role Overload

\begin{tabular}{|l|l|l|l|}
\hline $\begin{array}{l}\text { Sl. } \\
\text { No. }\end{array}$ & Role Overload & Mean & $\begin{array}{l}\text { Standard } \\
\text { Deviation }\end{array}$ \\
\hline 1. & $\begin{array}{l}\text { There is not enough } \\
\text { interactions between my } \\
\text { role and other roles }\end{array}$ & 3.39 & 1.36 \\
\hline 2. & $\begin{array}{l}\text { I work mostly under } \\
\text { pressure }\end{array}$ & 3.83 & 1.10 \\
\hline 3. & $\begin{array}{l}\text { I have to do things in my } \\
\text { job that are against my } \\
\text { judgment }\end{array}$ & 3.76 & 1.13 \\
\hline 4. & $\begin{array}{l}\text { I am asked to speed up } \\
\text { my job }\end{array}$ & 3.80 & 1.18 \\
\hline 5. & $\begin{array}{l}\text { My work load is too } \\
\text { heavy }\end{array}$ & 3.87 & 1.11 \\
\hline
\end{tabular}

Source: Primary Data

The workers of non-public sector banks are agreed with they work mostly under pressure, they have to do things in their job that are against their judgement, they are asked to speed up their job and their work load is too heavy, while, they are neutral with there is not enough interactions between their role and other roles.

\subsubsection{Job Difficulty}

The job difficulty of workers in non-public sector banks was studied and the results are shown in Tabular format -4 
Tabular format4: Job Difficulty

\begin{tabular}{|l|l|l|l|}
\hline $\begin{array}{l}\text { Sl. } \\
\text { No. }\end{array}$ & Job Difficulty & Mean & $\begin{array}{l}\text { Standard } \\
\text { Deviation }\end{array}$ \\
\hline 1. & $\begin{array}{l}\text { My job assignments are } \\
\text { quite difficult }\end{array}$ & 3.74 & 1.20 \\
\hline 2. & $\begin{array}{l}\text { My job assignments are } \\
\text { taxing my abilities }\end{array}$ & 3.78 & 1.15 \\
\hline 3. & $\begin{array}{l}\text { I do not get enough time } \\
\text { to finish my assignments }\end{array}$ & 3.84 & 1.01 \\
\hline 4. & $\begin{array}{l}\text { I am not able to look after } \\
\text { my personal things } \\
\text { effectively }\end{array}$ & 3.73 & 1.08 \\
\hline 5. & $\begin{array}{l}\text { I am not able to look after } \\
\text { my family matters } \\
\text { effectively }\end{array}$ & 3.90 & 1.03 \\
\hline
\end{tabular}

Source: Primary Data

The workers of non-public sector banks are agreed with their job assignments are quite difficult, their job assignments are taxing their abilities, they do not get enough time to finish their assignments, they are not able to look after their personal things effectively and they are not able to look after their family matters effectively.

\subsubsection{Role Stagnation}

The role stagnation of workers in non-public sector banks was studied and the results are shown in Tabular format 5

Tabular format5: Role Stagnation

\begin{tabular}{|l|l|l|l|}
\hline $\begin{array}{l}\text { SI. } \\
\text { No. }\end{array}$ & Role Stagnation & Mean & $\begin{array}{l}\text { Standard } \\
\text { Deviation }\end{array}$ \\
\hline 1. & $\begin{array}{l}\text { I wish I had been given } \\
\text { more challenging tasks to do } \\
\text { in the present job }\end{array}$ & 3.69 & 1.06 \\
\hline 2. & $\begin{array}{l}\text { I feel that I am not learning } \\
\text { enough in my present job for } \\
\text { taking up higher } \\
\text { responsibilities in future }\end{array}$ & 3.91 & 0.76 \\
\hline 3. & $\begin{array}{l}\text { I can easily succeed in the } \\
\text { present job }\end{array}$ & 3.35 & 1.39 \\
\hline 4. & $\begin{array}{l}\text { My assigned task is always } \\
\text { fixed }\end{array}$ & 3.29 & 1.30 \\
\hline 5. & $\begin{array}{l}\text { The higher position is } \\
\text { limited and it affects my } \\
\text { promotion }\end{array}$ & 3.88 & 0.99 \\
\hline
\end{tabular}

Source: Primary Data

The workers of non-public sector banks are agreed with they wish they had been given more challenging tasks to do in the present job, they feel that they are not learning enough in their present job for taking up higher responsibilities in future and the higher position is limited and it affects their promotion, while, they are neutral with they can easily succeed in the present job and their assigned task is always fixed.

\subsubsection{Lack of Group Cohesiveness}

The lack of group cohesiveness of workers in non-public sector banks was studied and the results are shown in Tabular format 6
Tabular format 6: Lack of Group Cohesiveness

\begin{tabular}{|l|l|l|l|}
\hline $\begin{array}{l}\text { Sl. } \\
\text { No. }\end{array}$ & $\begin{array}{l}\text { Lack ohesiveness } \\
\text { Coh Group }\end{array}$ & Mean & $\begin{array}{l}\text { Standard } \\
\text { Deviation }\end{array}$ \\
\hline 1. & $\begin{array}{l}\text { I work with subordinates } \\
\text { who work quite differently }\end{array}$ & 3.81 & 0.85 \\
\hline 2. & $\begin{array}{l}\text { My subordinates are not } \\
\text { very co-operative }\end{array}$ & 3.31 & 1.38 \\
\hline 3. & $\begin{array}{l}\text { Speed of technical change } \\
\text { does not create problems } \\
\text { while dealing with } \\
\text { subordinates }\end{array}$ & 3.33 & 1.37 \\
\hline 4. & $\begin{array}{l}\text { I feel that my superior } \\
\text { should consult me before } \\
\text { taking a decision in our } \\
\text { work } 3.86\end{array}$ & 1.13 \\
\hline 5. & $\begin{array}{l}\text { I feel that my superior is } \\
\text { unaware about the way his } \\
\text { people think and feel about } \\
\text { him }\end{array}$ & 1.82 \\
\hline
\end{tabular}

Source: Primary Data

The workers of non-public sector banks are agreed with they work with subordinates who work quite differently, they feel that their superior should consult them before taking a decision in their work and they feel that their superior is unaware about the way his people think and feel about him, while, they are neutral with their subordinates are not very co-operative and speed of technical change does not create problems while dealing with subordinates

\subsection{Level Of Job Stress}

The perception of workers about level of job stress in non-public sector banks was studied and the results are shown in Tabular format -7

Tabular format 7: Level of Job stress

\begin{tabular}{|l|l|l|l|}
\hline $\begin{array}{l}\text { Sl. } \\
\text { No. }\end{array}$ & $\begin{array}{l}\text { Level of Job } \\
\text { stress }\end{array}$ & $\begin{array}{l}\text { Number of } \\
\text { Workers }\end{array}$ & Percentage \\
\hline 1. & Low & 39 & 11.14 \\
\hline 2. & Moderate & 108 & 30.86 \\
\hline 3. & High & 203 & 58.00 \\
\hline & Total & $\mathbf{3 5 0}$ & $\mathbf{1 0 0 . 0 0}$ \\
\hline
\end{tabular}

Source: Primary Data

The results imply that $58.00 \%$ of workers viewed that the level of job stress at high level followed by moderate level $(30.86 \%)$ and low level $(11.14 \%)$.

\subsection{Relationship Between Causes Of Job Stress And} Level Of Stress Of Workers

The relationship between causes of job stress and level of stress of workers in non-public sector banks was studied by doing corrrelation analysis and the results are shown in Tabular format -8 
Tabular format 8: Relationship between Causes of Job stress and Level of Stress of Workers

\begin{tabular}{|c|c|c|c|c|c|c|c|}
\hline $\begin{array}{l}\text { Particul } \\
\text { ars }\end{array}$ & $\begin{array}{l}\text { Role } \\
\text { Conf } \\
\text { lict }\end{array}$ & $\begin{array}{l}\text { Role } \\
\text { Ambig } \\
\text { uity }\end{array}$ & $\begin{array}{l}\text { Role } \\
\text { Overl } \\
\text { oad }\end{array}$ & $\begin{array}{l}\text { Job } \\
\text { Diffic } \\
\text { ulty }\end{array}$ & \begin{tabular}{|l} 
Role \\
Stagna \\
tion
\end{tabular} & $\begin{array}{l}\text { Lack of } \\
\text { Group } \\
\text { Cohesive } \\
\text { ness }\end{array}$ & $\begin{array}{l}\text { Lev } \\
\text { el } \\
\text { of } \\
\text { Str } \\
\text { ess }\end{array}$ \\
\hline \begin{tabular}{|l|} 
Role \\
Conflict
\end{tabular} & 1.00 & & & & & & \\
\hline \begin{tabular}{|l|} 
Role \\
Ambigui \\
ty
\end{tabular} & ${ }_{*}^{0.17^{*}}$ & 1.00 & & & & & \\
\hline \begin{tabular}{|l|} 
Role \\
Overload \\
\end{tabular} & $0.25^{*}$ & $0.50^{* * *}$ & 1.00 & & & & \\
\hline \begin{tabular}{|l|} 
Job \\
Difficult \\
$\mathrm{y}$
\end{tabular} & ${ }_{*}^{0.33^{*}}$ & $0.22^{\text {*** }}$ & $0.36^{* *}$ & 1.00 & & & \\
\hline $\begin{array}{l}\text { Role } \\
\text { Stagnati } \\
\text { on }\end{array}$ & 0.11 & 0.12 & 0.09 & $0.23^{* *}$ & 1.00 & & \\
\hline \begin{tabular}{|l|} 
Lack of \\
Group \\
Cohesive \\
ness \\
\end{tabular} & ${ }_{*}^{0.29^{*}}$ & $0.37^{* *}$ & $0.34^{* *}$ & $0.17^{* *}$ & $0.19^{* * *}$ & 1.00 & \\
\hline \begin{tabular}{|l|} 
Level of \\
Stress
\end{tabular} & $0.41^{*}$ & $0.49^{* * *}$ & $0.52^{* *}$ & $0.47^{* *}$ & 0.44 & $0.48^{\text {** }}$ & 1.00 \\
\hline
\end{tabular}

The correlation coefficient between role conflict and level of stress of workers is 0.41 , which is moderately and positively associated with each other at one $\%$ level of significance.

The role ambiguity and level of stress of workers is moderately and positively correlated with each other with the value of 0.49 , which is significant at one $\%$ level.

The correlation coefficient between role overload and level of stress of workers is 0.52 , which is moderately and positively associated with each other at one \% level of significance.

The job difficulty and level of stress of workers is moderately and positively correlated with each other with the value of 0.47 , which is significant at one $\%$ level.

The role stagnation and level of stress of workers is moderately and positively correlated with each other with the value of 0.44 , which is significant at one \% level.

The correlation coefficient between lack of group cohesiveness and level of stress of workers is 0.48 , which is moderately and positively associated with each other at one $\%$ level of significance. So, the null hypothesis is rejected.

\section{CONCLUSION}

More than half $(52.00 \%)$ of workers of non-public sector banks are males and more than one third (34.86\%) of workers of non-public sector banks belong to the age group of 31 - 40 years. Nearly two fifth $(38.86 \%)$ of workers of non-public sector banks have educational qualification of post graduation and more than half $(51.43 \%)$ of workers of non-public sector banks are clerks.

Two fifth (39.71\%) of workers of non-public sector banks have work experience of 6 - 10 years and nearly one third $(32.29 \%)$ of workers of non-public sector banks belong to the monthly income group of Rs. 30,001- Rs. 40,000 . More than three fifth $(61.71 \%)$ of workers of non- public sector banks are married and three fifth $(59.71 \%)$ of workers of non-public sector banks belong to the nuclear family.

Nearly half (48.28\%) of workers of non-public sector banks have $3-5$ dependents and nearly half $(46.00 \%)$ of workers of non-public sector banks are working in branches located in urban area/

Role conflict, role ambiguity, role overload, job difficulty, role stagnation and lack of group cohesiveness are significantly and moderately related with the level of job stress of workers in non-public sector banks.

The non-public sector banks must communicate their workers clearly about their job priorities. The non-public sector banks should inform workers about different features of their roles and they must clearly communicate workers about what they have to do in their role.

The non-public sector banks should ensure workers in such a manner there is enough interactions between their role and roles of other workers. The non-public sector banks must have effective work life balance programmes for their workers in order to reduce their job difficulties and improve their job efficiency.

The non-public sector banks should make their workers more successful in their jobs through adequate trainings and skills development programmes and they must assign fixed duties and responsibilities for their workers.

The non-public sector banks should create better working environment in such a way that subordinates are highly cooperative with their superior workers and workers must accept the rapidity of technical changes that do not harm dealings of their subordinates.

The workers of non-public sector banks should ignore the issues and they must not leave the bank earlier. They should take one day leave and put efforts to solve the problems amicably.

The workers of non-public sector banks must take medical treatments to control or manage their health problems that are happened because of job stress. The workers of non-public sector banks should solve their problems through innovative methods and procedures.

The non-public sector banks must provide job security to their workers for a certain minimum period. The non-public sector banks should provide adequate opportunities for career development of their workers and they must create cooperation and unity among the workers.

\section{REFERENCES}

1 Vishal Samartha, Vidyavathi, and Mustiary Begum, (2013), "Regression Analysis of Stress - A eomparative Study of Workers in Public and Non-public sector Banks", EXCEL International Journal of Multidisciplinary Management Studies, 3(7):pp.68-76.

2 Sharmin Akther, Silvia Akter, and Md. Kafil Uddin,(2017), "Factors Influencing Job Stress in Privatized Banks of Bangladesh", Sona Global Management Review, 11(1):pp. 1-17.

3 Shavita Dhankar,(2015), "Job stress in Banking Sector", International Journal of Applied Research, 1(8): pp. 132 135. 
4 Sharmila, A., and Poornima, J.,(2012), "A Study on Employee Stress Management in Selected Private Banks in Salem", Elixir International Journal of Business Management, 42(1): pp. 6555-6558.

5 Rajeshwari, T.R., (1992), "Employee Stress: A Study with Reference to Bank Workers", Indian Journal of Industrial Relations, 27(4): pp. 419-429.

6 Niharika, and Kiran, U.V.,(2014), "Job stress among Bank Workers", European Academic Research, 2(4):pp.5404-5411.

7 Manshor, A. T., Fontaine, R., and Choy Chong Siong,(2003), "Job stress among Managers: A Malaysian Survey", Journal of Managerial Psychology, 18(6): pp 622-628.

8 Khan, A., Ramzan, M., and Butt, M.S.,(2013), "Is Job Satisfaction of Islamic Banks Operational Staff Determined through Organizational Climate, Job stress, Age and Gender", Journal of Business Studies Quarterly,4(3):pp.14-36.

9 Crandall, R., and Perrewe, P. L., (1995), "Job stress: A Handbook", CRC Press, New York, pp. 19-21.

10 Bano, B., and Jha, R., (2012), "Organizational Role Stress among Public and Private sector Workers", The Lahore journal of business, 12(1):pp. 23-26.

11 Anamika, (2016), "Stress and Job Satisfaction level among Government and Non-public sector Bank Workers: a Study on Urban Area in Patna India", The International Journal of Indian Psychology, 4(1):pp. 120127. 